\title{
PENGARUH KEGEL EXERCISE TERHADAP INKONTINENSIA URINE PADA LANSIA
}

\author{
Usan Daryaman \\ Program Studi Profesi Ners STIKes Dharma Husada Bandung \\ alzstar1528@gmail.com
}

\begin{abstract}
Abstrak
Lansia adalah seseorang yang telah memasuki usia 60 tahun ke atas. Pada kelompok yang dikategorikan lansia akan terjadi suatu proses yang disebut Aging Process. Perubahan fisik yang terjadi pada lanjut usia salah satunya pada sistem perkemihan yaitu penurunan tonus otot vagina dan otot pintu saluran kemih. Kajian Literatur ini bertujuan untuk mengetahui pengaruh keggel exercise terhadap inkontinensia urine pada lansia. Metode berupa analisis deskriptif dengan metode analisis data menggunakan Literature review. Semua jurnal temuan tersebut membahas tentang pengaruh keggel exercise terhadap inkontinensia urin pada lansia. Pencarian literature yang diakses melalui database yang digunakan dalam kajian literature review ini adalah : PubMed dan Google Scholar (https://schoolargoogle.co.id/). Dengan kata kunci Pengaruh kegel exercise, inkontinensia urine pada lansia, Efectiveness kegel exercise, efectiveness pelvic floor exercise. Hasil kajian literature review dari 20 jurnal menunjukan bahwa hanya satu jurnal yang memaparkan bahwa kegel exercise ini tidak memiliki perubahan yang signifikan pada lansia dengan inkontinensia urine. Sedangkan 19 jurnal lainnya mengatakan hal sebaliknya. keggel exercise ini terbukti dapat memperkuat otot - otot panggul atau pelvis sehingga dapat melatih dan memperkuat sfingter eksternal pada kandung kemih. Kesimpulannya adalah terdapat pengaruh inkontinensia urine sebelum dan sesudah dilakukan latihan keggel exercise pada lansia. Latihan keggel dapat mengurangi inkontinensia urine. Saran untuk peneliti selanjutnya diharapkan dapat menggunakan desain penelitian yang berbeda untuk membandingkan subjek penelitian pada variabel keggel exercise terhadap inkontinensia urine pada lansia.
\end{abstract}

Kata Kunci : keggel exercise, inkontinensia urine, lansia

\begin{abstract}
Elderly is someone who has entered the age of 60 years and over. In a group categorized as elderly, a process called the Aging Process will occur. One of the physical changes that occur in the elderly is in the urinary system, namely a decrease in the tone of the vaginal muscles and urinary tract muscles. This literature review aims to determine the effect of keggel exercise on urinary incontinence in the elderly. The method is descriptive analysis with data analysis method using Literature review. All of these journal findings discuss the effect of cricket exercise on urinary incontinence in the elderly. Literature searches accessed through the database used in this literature review are: PubMed and Google Scholar (https://schoolargoogle.co.id/). With the key words the effect of Kegel exercise, urinary incontinence in the elderly, the effectiveness of Kegel exercise, the effectiveness of pelvic floor exercise. The results of a literature review of 20 journals showed that only one journal presented that Kegel exercise did not have a significant change in the elderly with urinary incontinence. Meanwhile, 19 other journals said the opposite. This keggel exercise has been shown to strengthen the pelvic or pelvic muscles so that it can train and strengthen the external sphincter in the bladder. The conclusion is that there is an effect of urinary incontinence before and after the keggel exercise in the elderly. Keggel exercises can reduce urinary incontinence. Suggestions for future researchers are expected to be able to use a different research design to compare research subjects on the variable kggel exercise to urinary incontinence in the elderly.
\end{abstract}

Keywords: kegel exercise, urinary incontinence, elderly 


\section{PENDAhuluan}

Lanjut usia adalah suatu kejadian yang pasti akan dialami oleh semua orang yang dikarunia usia panjang. Menurut World Health Organisation (WHO) Lansia adalah seseorang yang telah memasuki usia 60 tahun ke atas. Lansia merupakan kelompok umur pada manusia yang telah memasuki tahapan dari fase akhir kehidupan. Semakin bertambahnya umur manusia, akan berdampak pada perubahan pada lanjut usia, seperti perubahan fisik, psikososial, dan spiritual. Perubahan fisik yang terjadi pada lanjut usia salah satunya pada sistem perkemihan yaitu penurunan tonus otot vagina dan otot pintu saluran kemih (uretra) yang disebabkan oleh penurunan hormon esterogen, sehingga menyebabkan terjadinya inkontinensia urine, otot-otot menjadi lemah, kapasitasnya menurun sampai $200 \mathrm{ml}$ atau menyebabkan frekuensi bak meningkat dan tidak dapat dikontrol (Mei Adelina Harahap, 2020). Inkontinensia urin merupakan gangguan pemenuhan kebutuhan eliminasi urine. Keadaan ini umumnya dijumpai pada manula.

Menurut data dari WHO, 200 juta penduduk di Dunia yang mengalami inkontinensia urin. Menurut National Kidney And Urologyc Disease Advisory Board di Amerika Serikat, jumlah penderita inkontinensia mencapai 13 juta dengan $85 \%$ diantaranya perempuan. Jumlah ini sebenarnya masih sangat sedikit dari kondisi sebenarnya, sebab masih banyak kasus yang tidak dilaporkan.

Data prevalensi inkontinensia di Indonesia didapatkan angka inkontinensia urin Jurnal Penelitian Kesehatan STIKes Dharma Husada Bandung pada tahun 2005 sebesar $10 \%$, pada tahun 2006 meningkat menjadi $12 \%$, dan semakin meningkat pada tahun 2007 yaitu sebesar 21\%, kemudian menurun pada tahun 2008 sebesar 9\%, dan naik lagi pada tahun 2013 sebesar 18\%, pada tahun 2018 mengalami peningkatan sebesar 30\% (Depkes 2018). Di Sumatera Utara pada tahun 2018 angka kejadian inkontinensia urine pada lansia sebesar $9.81 \%$ (Riskesdas, 2018). Lansia tidak menyadari bahwa ada pilihan lain dalam penanganan inkontinensia urine dengan terapi non farmakoligis, salah satu nya terapi non farmakoligis yaitu dengan teknik/latihan prilaku mengontrol kandung kemih dan otototot sfingter dengan latihan otot dasar panggul (Pelvicmuscteexercise) atau sering disebut dengan senam kegel. Latihan dasar panggul melibatkan kontraksi tulang otot pubokoksigeus, otot yang membentuk struktur penyokong panggul dan mengililingi pintu panggul pada vagina, uretra, dan rectum.

\section{METODE}

Metode pengumpulan data pada laporan skripsi ini penulis mengakses melalui internet untuk mengambil dan menganalisis beberapa data dalam bentuk literature, literatur internasional sebanyak 4 jurnal dan literatur nasional sebanyak 16 jurnal, sehingga literatur yang digunakan sebanyak 20 jurnal. Jenis penelitian ini adalah penelitian kepustakaan (Library Research). Sifat dari penelitian ini adalah analisis deskriptif. Sumber data yang digunakan dalam penelitian ini adalah sumber data sekunder 
Pencarian literatur diakses melalui database yang ada di perpustakaan elektronik. Database yang digunakan dalam penelitian kajian literatur review ini adalah : PubMed dan Google Scholar (https://schoolargoogle.co.id/). Adapun pencarian dalam kajian literatur untuk mencari kata kunci, peneliti menggunakan metode PICO (Population/Problem; Intervention; Comparison; Outcome). Metode analisis data yang digunakan adalah dengan menggunakan Literature review matrix yaitu dengan menggabungkan berbagai jurnal internasional maupun nasional yang bersifat relevan, mutakhir, dan memadai

\section{HASIL DAN PEMBAHASAN}

Berdasarkan dari beberapa jurnal yang dianalisis penulis dapat menggolongkannya menjadi beberapa garis besar mengenai Pengaruh kegel exercise terhadap inkontinensia urine pada lansia. Ada beberapa yang dapat dikategorikan yaitu Pengaruh kegel exercise terhadap inkontinensia urine pada lansia.

\section{a. Inkontinensia Urine pada Lansia Sebelum melakukan Kegel Exercise}

Berdasarkan penelitian yang dilakukan oleh Dewi Hartinah dan Yulisetyaningrum tahun 2016 mengatatakan bahwa Distribusi Inkontinensia Urine Pada Kelompok Perlakuan dan Kontrol Sebelum dan Sesudah Dilakukan Kegel exercise menunjukkan bahwa inkontinensia urine dalam kelompok perlakuan (pre) adalah buruk sejumlah 10 orang $(66,6 \%)$ sedangkan inkontinensia urine dalam kelompok perlakuan (post) adalah baik dengan jumlah 12 orang (80\%). Untuk inkontinensia Jurnal Penelitian Kesehatan STIKes Dharma Husada Bandung urine dalam kelompok kontrol (pre) adalah buruk dengan 13 orang $(86,6)$ dan untuk kontrol (post) adalah 12 orang (80\%).

Hasil penelitian yang dilakukan oleh Dahlan D.A, dan Martinimgsih tahun 2014 menunjukan frekwensi berkemih lansia sebelum dilakukan latihan kegel terdapat 32,5 $\%$ yang mengalami inkontinensia urin sedang dengan frekwensi berkemih $6-10$ kali sehari, serta terdapat $5 \%$ lansia yang mengalami inkontinentia urine berat dengan frekwensi berkemih lebih dari 10 kali sehari. Hal ini dapat dihubungkan dengan usia lansia yang menjadi responden yang kebanyak sudah dalam rentang 70-75 tahun (52,5\%) sehingga masih dapat mengontrol kognitifnya dalam hal berkemih.

Penelitian ini pun sesuai dengan penelitian yang dilakukan oleh Dr. G.Bhuvaneswari di Chennai, pada tes awal didapatkan hasil yang buruk di antara 60 sampel. Penuaan menyebabkan penurunan kekuatan otot diantaranya otot dasar panggul, serta mengendalikan dan mengontrol defekasi dan berkemih.

\section{b. Inkontinensia Urine pada Lansia Sesudah melakukan Kegel Exercise}

Berdasarkan penelitian yang dilakukan oleh Julianti Dewi tahun 2017 menunjukkan bahwa frekuensi inkontinensia urine tertinggi adalah frekuensi inkontinensia jarang sebanyak 25 orang (83.3\%) dan frekuensi inkontinensia terendah sebanyak 5 orang (16.7\%) pada frekuensi inkontinensia urine sedang. Menurut hasil penelitian Masyitah Wahab tahun 2018 mengatakan bahwa 
inkontinensia urin sesudah latihan kegel exercise involunter sebanyak 2 responden $(14,3 \%)$, responden involunter tersebut diakibatkan karena latihan Kegel Exercise responden ini kurang maksimal yang harusnya dilakkukan tiga kali seminggu selama empat minggu tetapi tidak dilakukan, dan responden dengan inkontinensia urine volunter sebelum melakukan latihan kegel exercise sebanyak 4 responden $(28,6 \%)$ dan setelah melakukan latihan kegel meningkat menjadi 12 responden $(85,7 \%)$. Responden yang mengalami volunter diakibatkan karena latihan Kegel Exercise responden ini dilakkukan tiga kali seminggu selama empat minggu.

Penelitian ini sejalan dengan penelitian yang dilakukan oleh Mei Adelina Harahap, Nur Aliyah Rangkuti tahun 2020 menyatakan distribusi inkontinensia urine pada kelompok perlakuan dan kontrol sebelum dan sesudah dilakukan kegel exercise menunjukkan bahwa inkontinensia urine dalam kelompok perlakuan (pre) adalah buruk sejumlah 10 orang $(66,6 \%)$ sedangkan inkontinensia urine dalam kelompok perlakuan (post) adalah baik dengan jumlah 12 orang $(80 \%)$. Untuk inkontinensia urine dalam kelompok kontrol (pre) adalah buruk dengan 13 orang $(86,6)$ dan untuk kontrol (post) adalah 12 orang (80\%). didapatkan hasil $p$ value $0,000(\mathrm{p}(\mathrm{p}<0,05)$ sehingga ada pengaruh senam kegel terhadap frekuensi inkontinensia urin pada lansia. Persentase ini menunjukkan bahwa terjadi penurunan gejala inkontinensia urin post intervensi latihan kegel. Latihan kegel sangat bermanfaat untuk menguatkan otot rangka pada dasar panggul, sehingga memperkuat fungsi sfingter eksternal pada kandung kemih

\section{c. Pengaruh kegel exercise terhadap inkontinensia urine pada lansia}

Berdasarkan penelitian yang dilakukan oleh Dewi Hartinah dan Yulisetyaningrum tahun 2016 ada pengaruh kegel exercise terhadap penurunan inkontinensia urin pada lansia di Desa Undaan Lor Kabupaten Kudus dengan nilai $\mathrm{p}=0,002(\mathrm{p} 0,05)$ pada kelompok kontrol.

Menurut hasil penelitian Masyitah Wahab tahun 2018 Berdasarkan hasil uji Mc. Nemar diperoleh hasil nilai signifikansi $p$ value $=(p<$ $0,05)$ dengan nilai $\mathrm{p}=0,021<0,05$ hal ini menunjukkan bahwa nilai $\mathrm{p}$ value lebih kecil dari standar signifikansi 0,05 maka $\mathrm{Ha}$ diterima. Dengan demikian terdapat bahwa ada pengaruh antara latihan kegel exercise terhadap inkontinensia urine pada usia pra lansia 45 tahun dikarenakan kekuatan otot dasar panggul meningkat dan menguatkan otot dasar panggul pada wanita. Sehingga inkontinensia urine dapat berkurang atau disadari.

Pada usia lanjut, penuaan dapat menyebabkan penurunan kekuatan otot diantaranya otot dasar panggul, sehingga kontrol terhadap defekasi dan berkemih berkurang dan dapat menyebabkan terjadinya inkontinens ia urin pada lansia. Latihan kegel yang dilakukan pada lansia mempunyai efektifitas untuk menguatkan otot-otot pubbococygeal yang menyangga kandung kemih dan sfingter uretra serta meningkatkan 
kemampuan untuk memulai dan menghentikan laju urin

\section{KESIMPULAN}

Berdasarkan kajian literature yang telah dilakukan dari 20 jurnal dapat disimpulkan bahwa :

\section{a. Inkontinensia Urine pada Lansia Sebelum melakukan Kegel Exercise}

Dari hasil analisis 20 jurnal yang telah dilakukan, didapatkan hasil bahwa lansia yang mengalami inkontinensia urine dan belum menjalani kegel exercise mengalami frekuensi berkemih yang sedang hingga buruk, hal ini disebabkan oleh faktor kognitif, tekanan intra abdominal, usia serta jenis kelamin, karena secara fisiologis, pada lansia wanita terjadi penurunan produksi estrogen yang menyebabkan penurunan atrofi jaringan uretra dan adanya efek akibat melahirkan sehingga melemahnya otot-otot dasar panggul.

\section{b. Inkontinensia Urine pada Lansia Sesudah melakukan Kegel Exercise}

Dari hasil analisis 20 jurnal, didapatkan hasil bahwa lansia yang sudah melakukan kegel exercise mengalami penurunan frekuensi berkemih setelah dilakukannya kegel exercise. Hal ini disebabkan karena latihan kegel ini sangat bermanfaat untuk meningkatkan kekuatan otot-otol pelvis atau panggul sehingga dapat memperkuat sfingter eksternal pada kandung kemih.

\section{c. Pengaruh kegel exercise terhadap inkontinensia urine pada lansia}

Dari hasil analisis jurnal yang telah dilakukan, didapatkan kesimpulan bahwa dari 20 jurnal, hanya satu jurnal yang memaparkan bahwa kegel exercise ini tidak memiliki perubahan yang signifikan pada lansia dengan inkontinensia urine. Sedangkan 19 jurnal lainnya mengatakan hal sebaliknya. Sehingga penulis menyimpulkan bahwa kegel exercise ini terbukti dapat memperkuat otot - otot panggul atau pelvis sehingga dapat melatih dan memperkuat sfingter eksternal pada kandung kemih.

\section{DAFTAR PUSTAKA}

Amilia, S., Warjiman, W., \& Ivana, T. (2018). PENGARUH SENAM KEGEL TERHADAP PENURUNAN GEJALA INKONTINENSIA URIN PADA LANSIA WANITA DI PANTI SOSIAL TRESNA WERDHA BUDI SEJAHTERA. JURNAL KEPERAWATAN SUAKA INSAN (JKSI), 3(2), 1-9.

Ananingsih, E. S., Ristriana, R., \& Suhairy, L. (2014). Pengaruh Latihan Kegel Terhadap Perubahan Inkontinensia Pada Lansia Di Panti Sosial Tresna Werdha Teratai Palembang Tahun 2013. JPP (Jurnal Kesehatan Poltekkes Palembang), 2(14).

Karjoyo, J. D., Pangemanan, D., \& Onibala, F. (2017). Pengaruh Senam Kegel Terhadap Frekuensi Inkontinensia Urine Pada Lanjut Usia Di Wilayah Kerja Puskesmas Tumpaan Minahasa Selatan. Jurnal Keperawatan, 5(1).

Radzimińska, A., Strączyńska, A., WeberRajek, M., Styczyńska, H., Strojek, K., \& Piekorz, Z. (2018). The impact of pelvic floor muscle training on the quality of life of women with urinary incontinence: a 
systematic literature review. Clinical interventions in aging, 13, 957.

Novalinda, D. (2020). ASUHAN KEPERAWATAN KELUARGA PADA LANSIA Ny. E DENGAN INKONTINENSIA URIN MELALUI PENERAPAN KEGEL EXERCISE DI RW 19 KELURAHAN SURAU GADANG KECAMATAN NANGGALO (Doctoral dissertation, Universitas Andalas).

Novera, M. (2017). Pengaruh Senam Kegel Terhadap Frekuensi Bak Pada Lansia Dengan Inkontinensia Urine. Jurnal Ipteks Terapan Research of Applied Science and Education, 7.

Ong, T. A., Khong, S. Y., Ng, K. L., Ting, J. R. S., Kamal, N., Yeoh, W. S., ... \& Razack, A. H. (2015). Using the Vibrance Kegel device with pelvic floor muscle exercise for stress urinary incontinence: a randomized controlled pilot study. Urology, 86(3), 487-491.

Rangkuti, N. A., \& Harahap, M. A. (2020). HUBUNGAN PENGETAHUAN DAN USIA IBU HAMIL DENGAN KEHAMILAN RISIKO TINGGI DI PUSKESMAS LABUHAN RASOKI. JURNAL EDUCATION AND DEVELOPMENT, 8(4), 513-513

Relida, N., \& Ilona, Y. T. (2020). PENGARUH PEMBERIAN SENAM KEGEL UNTUK MENURUNKAN DERAJAT INKONTINENSIA URIN PADA LANSIA. Jurnal Ilmiah Fisioterapi (JIF), 3(1), 18-24 